\title{
THE SENSITIVITY OF STAPHYLOCOCCI AND OTHER WOUND BACTERIA TO ERYTHROMYCIN, OLEANDOMYCIN, AND SPIRAMYCIN
}

\author{
BY \\ E. J. L. LOWBURY AND L. HURST \\ From the Medical Research Council Industrial Injuries and Burns Research Unit, \\ Birmingham Accident Hospital
}

(RECEIVED FOR PUBLICATION APRIL 21, 1958)

Sensitive strains of Staphylococcus aureus can acquire resistance to all three of the antibiotics erythromycin, oleandomycin, and spiramycin when grown in culture media containing subinhibitory concentrations of any one of them (Jones, Nichols, and Finland, 1956). In contrast with the uniform pattern of resistance to the tetracyclines, however, staphylococci isolated from patients are often described as resistant to one antibiotic of the erythromycin group and sensitive to another (Hudson, Yoshihara, and Kirby, 1956 ; Ross, 1956; Needham and Geraci, 1956). Garrod (1957) used the term "dissociated resistance" to describe the state of organisms resistant to erythromycin but sensitive to oleandomycin or to spiramycin; he has shown that cultures of such strains include a minority of erythromycinresistant organisms, and these grow selectively in the presence of erythromycin.

Following the increased therapeutic use of erythromycin, many burns in this Unit carry erythromycin-resistant staphylococci (Lowbury, 1957). In routine sensitivity tests by a ditch plate method, erythromycin-resistant strains were sometimes resistant to oleandomycin, but more often sensitive or moderately sensitive to that antibiotic; on continued incubation of the test cultures for a further 24 hours, however, strains showing this dissociated resistance to erythromycin usually appeared to have become resistant also to oleandomycin. Such findings were supported by tube dilution tests.

In this paper data are given on the incidence of dissociated and cross resistance of Staph. aureus from burns, and experiments are described which throw light on the apparently transient oleandomycin sensitivity of erythromycin-resistant strains. Some notes also are included on the sensitivity and resistance of Streptococcus pyogenes and Clostridium welchii to these antibiotics.

\section{SENSITIVITY OF STAPHYLOCOCCUS AUREUS FROM BURNS TO THE ERYTHROMYCIN ANTIBIOTICS}

\section{Materials and Methods}

Strains of coagulase-producing staphylococci (Staph. aureus) were isolated from burns of in-patients and examined by methods most of which are described elsewhere (Lowbury, Topley, and Hood, 1952).

Since February, 1957, all strains of Staph. aureus have been tested for sensitivity to erythromycin and, for separate periods, to oleandomycin, to spiramycin, and to both of these antibiotics. A ditch plate method was used, parallel ditches being cut from opposite sides of a horse blood agar plate and filled with nutrient agar containing $10 \mu \mathrm{g} . / \mathrm{ml}$. of the antibiotics (except spiramycin, which in the later months of the study was included at a concentration of $50 \mu \mathrm{g}$. per ml.). Small loopfuls of undiluted overnight broth culture were inoculated on this medium, the loop being carried from the middle of the plate first across one ditch and then across the other. A sensitive and a resistant control strain were inoculated on every plate. The plates were incubated at $37^{\circ} \mathrm{C}$. and examined with the naked eye after 18 hours' and again after 42 hours' incubation. The manner of reading and recording is described under Results and in the footnote to Table I.

Staphylococci were tested by the same method (including readings at 42 hours on 579 strains) for sensitivity to penicillin, tetracycline, chloramphenicol, and novobiocin. A number of strains, representing different patterns of resistance in the ditch plate test, were tested by tube dilution and plate dilution methods; doubling dilutions of the antibiotics were incorporated in nutrient agar or broth, and these were inoculated with undiluted and with a 1/500 dilution of overnight broth culture, one drop $(0.02 \mathrm{ml}$.) in the tube test and a loopful in the plate test. 
TABLE I

620 STRAINS OF STAPHYLOCOCCUS AUREUS ISOLATED DURING FOUR WEEKS OF 1957 SHOWING PATTERNS OF SENSITIVITY BY DITCH-PLATE TESTS READ AT 18 HOURS AND AT 42 HOURS

\begin{tabular}{|c|c|c|c|c|c|c|c|c|c|c|c|c|c|c|c|c|}
\hline \multirow{3}{*}{$\begin{array}{l}\text { Sensitivity to } \\
\text { Erythromycin* }\end{array}$} & \multicolumn{8}{|c|}{ Sensitivity to Oleandomycin } & \multicolumn{8}{|c|}{ Sensitivity to Spiramycin } \\
\hline & \multicolumn{4}{|c|}{ Test Read at 18 Hours } & \multicolumn{4}{|c|}{ Test Read at 42 Hours } & \multicolumn{4}{|c|}{ Test Read at 18 Hours } & \multicolumn{4}{|c|}{ Test Read at 42 Hours } \\
\hline & $\mathbf{S}$ & “s $"$ & “ $\mathbf{R} " \mid$ & $\mathbf{R}$ & $\mathbf{S}$ & $" S "$ & “ $\mathbf{R} " \mid$ & $\mathbf{R}$ & $\mathbf{S}$ & "S" & " $\mathbf{R} " \mid$ & $\mathbf{R}$ & $\mathbf{S}$ & “ $\mathrm{S} "$ & | $\mathbf{R} " \mid$ & $\mathbf{R}$ \\
\hline $\begin{array}{l}\mathbf{S} \\
\text { “ } \\
\text { “ } \\
\mathbf{R}\end{array}$ & $\begin{array}{r}267 \\
1 \\
11 \\
24\end{array}$ & $\begin{array}{r}0 \\
1 \\
7 \\
129\end{array}$ & $\begin{array}{r}0 \\
3 \\
0 \\
71\end{array}$ & $\begin{array}{r}0 \\
20 \\
5 \\
81\end{array}$ & $\begin{array}{r}262 \\
1 \\
1 \\
3\end{array}$ & $\begin{array}{r}3 \\
1 \\
9 \\
26\end{array}$ & $\begin{array}{r}0 \\
2 \\
4 \\
17\end{array}$ & $\begin{array}{r}2 \\
21 \\
99 \\
259\end{array}$ & $\begin{array}{r}265 \\
2 \\
18 \\
239\end{array}$ & $\begin{array}{r}2 \\
23 \\
5 \\
66\end{array}$ & $\begin{array}{l}0 \\
0 \\
0 \\
0\end{array}$ & $\begin{array}{l}\mathbf{0} \\
0 \\
0 \\
0\end{array}$ & $\begin{array}{r}265 \\
2 \\
18 \\
238\end{array}$ & $\begin{array}{r}2 \\
23 \\
5 \\
67\end{array}$ & $\begin{array}{l}0 \\
0 \\
0 \\
0\end{array}$ & $\begin{array}{l}\mathbf{0} \\
0 \\
0 \\
0\end{array}$ \\
\hline Total & 303 & 137 & 74 & 106 & 267 & 39 & 23 & 291 & 524 & 96 & 0 & 0 & 523 & 97 & 0 & 0 \\
\hline
\end{tabular}

* Readings of the test after 42 hours' incubation; these were the same as at 18 hours in all except seven strains, which appeared more resistan after the longer period of incubation. $S=Z$ one of inhibition the same as that of sensitive control. " $S$ " $=Z$ one of inhibition narrower than that of sensitive control. " $\mathbf{R} "=\mathbf{G r o w t h}$ up to but not across antibiotic-containing ditch. $\mathbf{R}=\mathbf{G r o w t h}$ extends across ditch.

Growth curves of staphylococci from small inocula in broth with and without the antibiotics oleandomycin and erythromycin were constructed from series of viable counts made by the method of Miles, Misra, and Irwin (1938).

A selection of strains was phage-typed by the method of Williams and Rippon (1952).

Habituation of a number of sensitive strains of Staph. aureus to growth in the presence of the antibiotics was carried out by serial transfer in fluid media, as described elsewhere (Lowbury, 1957).

\section{Results}

Table I shows the sensitivity to erythromycin, oleandomycin, and spiramycin by ditch plate tests of 620 strains of Staph. aureus isolated during a period of four weeks in 1957. The strains are classified as fully sensitive (S) or showing three degrees of resistance (" $S$," " $R$," and $R$ ) defined in the footnote to the Table.

Strains recorded as sensitive (S) to erythromycin were all fully sensitive to oleandomycin after 18 hours, and almost all remained fully sensitive after 42 hours' incubation. The same strains were almost always fully sensitive to spiramycin after 18 hours' and 42 hours' incubation.

Strains which showed more resistance to erythromycin fell into two groups: $(a)$ the small number which were slightly resistant to erythromycin ("S") were nearly always fully resistant to oleandomycin after 18 hours' incubation, and usually slightly resistant ("S ") to spiramycin. (b) Strains which were more resistant

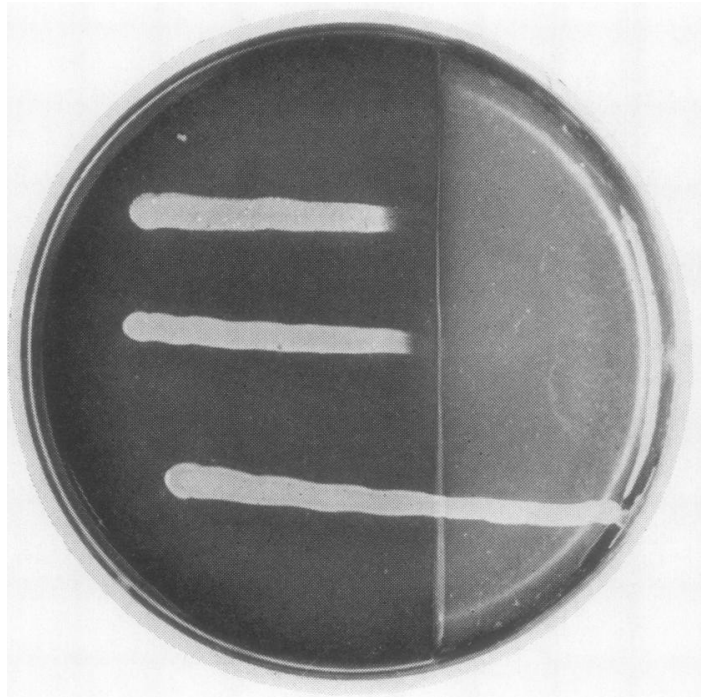

18 hours

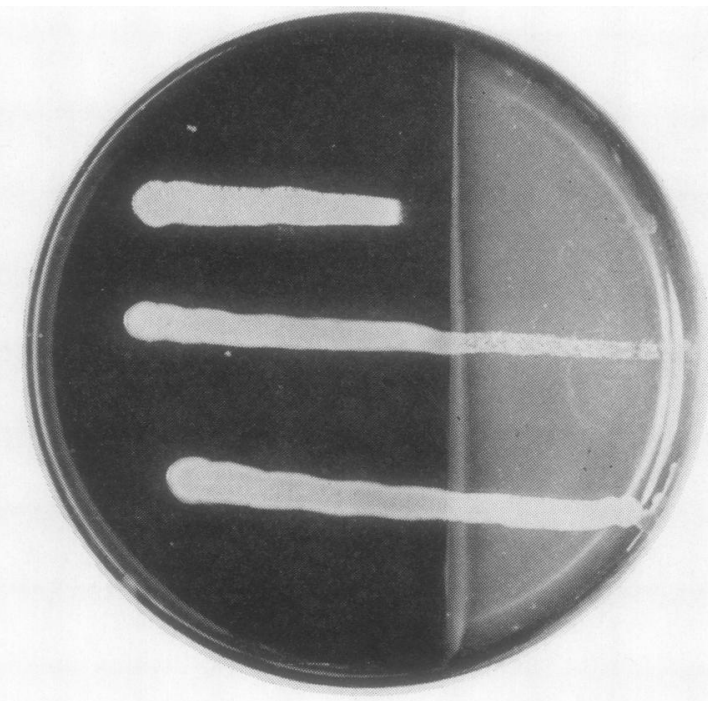

42 hours

FIG. 1.-An oleandomycin ditch plate test on three strains of Staph. aureus photographed after incubation for 18 hours (left) and 42 hours (right). The strain in the middle, which appears moderately sensitive at 18 hours but resistant at 42 hours, was resistant to erythromycin. Above it is a strain sensitive to erythromycin and oleandomycin, and below a strain resistant to both antibiotics. 
to erythromycin (" $R$ " and $R$ ) were usually intermediate in their resistance to oleandomycin (" $S$ " or " $R$ ") after 18 hours" incubation, but had in most cases become fully resistant after 42 hours' incubation. About one quarter of these showed some degree of resistance to spiramycin. Spiramycin sensitivity was the same after 18 hours' and 42 hours' incubation of the test plates. The different patterns of sensitivity and resistance after 18 hours' and 42 hours' incubation of an oleandomycin ditch plate are illustrated in Fig. 1.

Tests carried out in parallel with this series of staphylococci on ditch plates containing tetracycline, penicillin, chloramphenicol, and novobiocin showed that heavy delayed growth of staphylococci across the ditch on continued incubation virtually never occurred with these antibiotics, or with spiramycin or erythromycin. On some plates there was some thin delayed growth across the tetracycline ditch, apparently due to the relative instability of tetracycline; this mechanism, however, cannot be invoked to explain the delayed growth of erythromycin-resistant staphylococci in the presence of oleandomycin, for no loss in potency of that antibiotic could be detected after 42 hours' incubation.

Staphylococci showing dissociated resistance to erythromycin were often found to grow over the erythromycin ditch-and, after 42 hours, over the oleandomycin ditch-in the form of semiconfluent growth or large discrete colonies even when the growth at a distance from the antibiotic ditch was confluent. This suggests that only a fraction of the organisms of such a strain are resistant to erythromycin and, on further incubation, to oleandomycin.
The separate tests of oleandomycin and spiramycin sensitivity which were made on staphylococci from burns during the greater part of 1957 were quite consistent with the results of the study summarized in Table I. One additional feature was the presence in a small number of burns of staphylococci more resistant to spiramycin than those recorded in the Table. Several of these were isolated from patients who had received spiramycin therapy and from other patients who were in the ward at the same time.

Table II shows the results of tube and plate dilution tests on 36 strains of Staph. aureus, 12 being fully sensitive (ES, OS, SS) and 12 resistant (ER, OR, SR) to erythromycin, oleandomycin, and spiramycin by ditch plate tests. The remaining 12 strains were, by the same criteria, resistant to erythromycin, sensitive to spiramycin, and moderately sensitive to oleandomycin (ER, O " $\mathrm{S}$," SS). In all the tests two bacterial inocula, 1 in 1 and 1 in 500, were used. There was no appreciable difference between readings at 18 hours and at 42 hours, or between the results of tests with the different inocula, except in the case of oleandomycin. The minimal inhibitory concentration (M.I.C.) of this antibiotic was appreciably higher in tests done with larger inocula of strains ES, OS, SS, and ER, O "S," SS ; only strains of pattern ER, O " $S$," SS showed a higher M.I.C. of oleandomycin when tests were read after 42 hours' than after 18 hours' incubation. There was no consistent difference in the results of tube and plate dilution tests.

Fig. 2 shows the effects of oleandomycin on the growth curves of three strains of Staph.aureus, one of each sensitivity pattern. In the presence

TABLE II

SENSITIVITY OF STAPHYLOCOCCUS AUREUS BY TUBE AND PLATE DILUTION TESTS

\begin{tabular}{|c|c|c|c|c|c|c|c|c|c|}
\hline \multirow{2}{*}{$\begin{array}{c}\text { Sensitivity } \\
\text { Pattern by } \\
\text { Ditch Plate } \\
\text { Test* }\end{array}$} & \multirow{2}{*}{ Strains } & \multirow{2}{*}{ Test } & \multirow{2}{*}{$\begin{array}{l}\text { Bacterial } \\
\text { Inoculum }\end{array}$} & \multicolumn{2}{|c|}{$\begin{array}{l}\text { M.I.C. } \dagger \text { Erythromycin } \\
(\mu \mathrm{g} . \text { per ml. })\end{array}$} & \multicolumn{2}{|c|}{$\begin{array}{l}\text { M.I.C. Oleandomycin } \\
(\mu \mathrm{g} . \text { per ml. })\end{array}$} & \multicolumn{2}{|c|}{$\begin{array}{l}\text { M.I.C. Spiramycin } \\
(\mu \mathrm{g} . \text { per ml.) }\end{array}$} \\
\hline & & & & 18 Hours & 42 Hours & 18 Hours & 42 Hours & 18 Hours & 42 Hours \\
\hline \multirow[t]{2}{*}{ ES, OS, SS } & \multirow[t]{2}{*}{12} & Tube & ${ }_{1500}^{10^{\circ}}$ & $\begin{array}{l}0.4 \\
0 \cdot 2\end{array}$ & $\begin{array}{l}0.4-0.8 \\
0.2-0.4\end{array}$ & $\begin{array}{l}1 \cdot 6-6 \cdot 25 \\
0 \cdot 8\end{array}$ & $\begin{array}{c}1 \cdot 6-6 \cdot 25 \\
1 \cdot 6\end{array}$ & $\begin{array}{c}6 \cdot 25 \\
6 \cdot 25-12 \cdot 5\end{array}$ & $\begin{array}{l}6 \cdot 25-50 \cdot 0 \\
12 \cdot 5-25 \cdot 0\end{array}$ \\
\hline & & Plate & $\begin{array}{l}10^{\circ} \\
1 / 500\end{array}$ & $\begin{array}{l}0 \cdot 2 \\
0 \cdot 2\end{array}$ & $\begin{array}{l}0.2-0.4 \\
0.2-0.4\end{array}$ & $\begin{array}{l}1.6-3 \cdot 12 \\
0.4-0.8\end{array}$ & $\begin{array}{l}3 \cdot 12-6 \cdot 25 \\
0 \cdot 8-1 \cdot 6\end{array}$ & $\begin{array}{l}6 \cdot 25-12 \cdot 5 \\
6 \cdot 25-12 \cdot 5\end{array}$ & $\begin{array}{l}12 \cdot 5-25 \cdot 0 \\
12 \cdot 5-25 \cdot 0\end{array}$ \\
\hline \multirow[t]{2}{*}{$\mathrm{ER}, \mathrm{O}$ “S," SS } & \multirow[t]{2}{*}{12} & Tube & $\begin{array}{c}10^{\circ} \\
1: 500\end{array}$ & $\begin{array}{l}>100 \\
>100\end{array}$ & $\begin{array}{l}>100 \\
>100\end{array}$ & $\begin{array}{l}3 \cdot 12-12 \cdot 5 \\
0 \cdot 8-3 \cdot 12\end{array}$ & $\begin{array}{l}25->100 \\
3 \cdot 12-100\end{array}$ & $\begin{array}{c}6 \cdot 25-25 \cdot 0 \\
12 \cdot 5\end{array}$ & $\begin{array}{l}12 \cdot 5-25 \cdot 0 \\
12 \cdot 5-25 \cdot 0\end{array}$ \\
\hline & & Plate & $\begin{array}{l}10^{\circ} \\
1500\end{array}$ & $\begin{array}{l}>100 \\
>100\end{array}$ & $\begin{array}{l}>100 \\
>100\end{array}$ & $\begin{array}{l}3 \cdot 12-12 \cdot 5 \\
1 \cdot 6-3 \cdot 2\end{array}$ & $\begin{array}{l}50->100 \\
6 \cdot 3-100\end{array}$ & $\begin{array}{c}6 \cdot 25-12 \cdot 5 \\
6 \cdot 25\end{array}$ & $\begin{array}{c}12 \cdot 5-50 \cdot 0 \\
6 \cdot 25\end{array}$ \\
\hline \multirow[t]{2}{*}{ ER, OR, SR } & \multirow[t]{2}{*}{12} & Tube & $\begin{array}{l}10^{\circ} \\
1500\end{array}$ & $\begin{array}{l}>100 \\
>100\end{array}$ & $\begin{array}{l}>100 \\
>100\end{array}$ & $\begin{array}{l}>100 \\
>100\end{array}$ & $\begin{array}{l}>100 \\
>100\end{array}$ & $\begin{array}{c}50-100 \\
25 \cdot 0-50 \cdot 0\end{array}$ & $\begin{array}{l}50-100 \\
50-100\end{array}$ \\
\hline & & Plite & $\begin{array}{l}10^{\circ} \\
1500\end{array}$ & $\begin{array}{l}>100 \\
>103\end{array}$ & $\begin{array}{l}>100 \\
>100\end{array}$ & $\begin{array}{l}>100 \\
>100\end{array}$ & $\begin{array}{l}>100 \\
>100\end{array}$ & $\begin{array}{c}50-100 \\
100\end{array}$ & $\underset{103}{100->100}$ \\
\hline
\end{tabular}

*ES, OS, SS = “ sensitive to erythromycin, oleandomycin, and spiramycin." For key to grades of resistance, sze footnote to Table I. $\dagger$ M.I.C. $=$ minimal inhibitory concentration. 


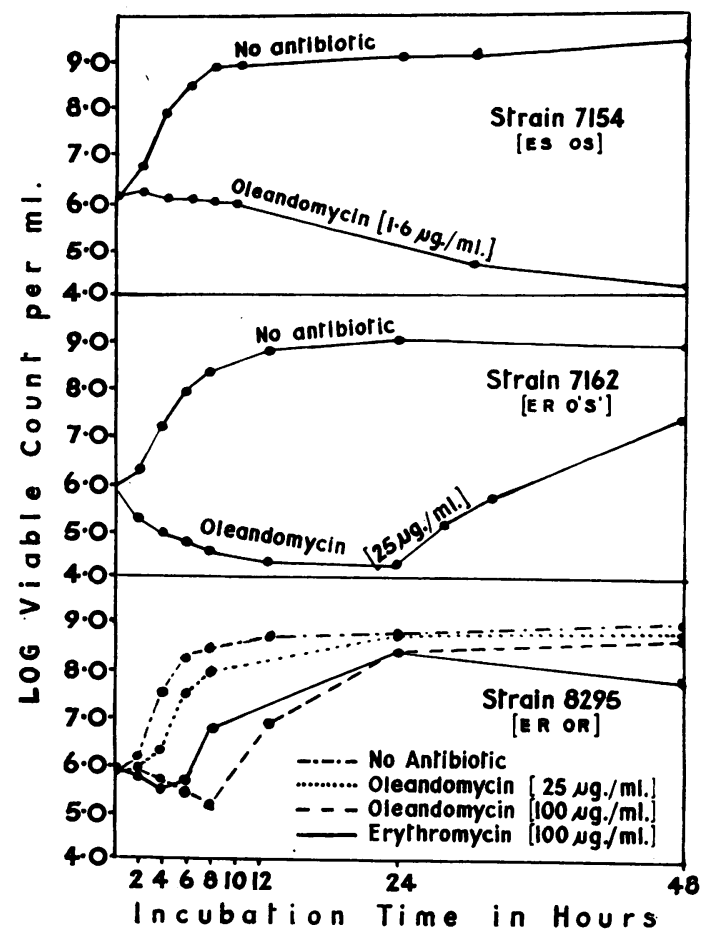

FIG. 2.-Growth curves of staphylococci showing sensitivity patterns (from above downward) ES, OS, ER, O " $S$," and ER, OR in the presence and absence of oleandomycin; in the lowest chart a growth curve of the staphylococci ER, OR in the presence of erythremycin is also presented. Note the long delay before growth of strain ER, $O$ " $S$ " began in the presence of oleandomycin.

of oleandomycin (1.6 $\mu \mathrm{g}$. per ml.) the fully sensitive strain (ES OS) showed a progressive fall in viable count during the 48 hours of the test ; the resistant strain (ER OR) exposed to oleandomycin, $25 \mu \mathrm{g}$. per $\mathrm{ml}$., grew well, but in broth containing $100 \mu \mathrm{g}$. per ml. of oleandomycin (or erythromycin) there was an initial drop in viable count before growth started ; the strain ER $O$ " $S$ " showed a drop in viable count during the first 24 hours, after which it grew well.

\section{Phage Types of Staph. aureus Showing Different Sensitivity Patterns}

Staphylococci showing the sensitivity pattern ES, OS, SS included a larger proportion of strains of phage group II than those showing dissociated or cross resistance to the erythromycin group of antibiotics; most of the latter showed various phage patterns belonging to group III, and in the series with sensitivity pattern ER, O " $S$," SS were several strains of type 80 .
Cross-resistance after Habituation in vitro.Attempts failed to obtain dissociated resistance to erythromycin (cf. Garrod, 1957) by daily subculture of sensitive strains in media containing increasing concentrations of erythromycin, and by exposing them for several days to a low concentration of the antibiotic ( $5 \mu \mathrm{g}$. per ml.) such as might be expected in wound exudate. By both methods resistance, when it emerged, was against oleandomycin as well as erythromycin. Most of 40 sensitive staphylococci tested which did not acquire resistance died on exposure for more than two days to $5 \mu \mathrm{g}$. erythromycin per $\mathrm{ml}$.

In tests on the habituation of staphylococci to spiramycin considerable variation was found between strains in the degree of cross-resistance that appeared. For example, in Table III are shown the results after transfer of seven

TABLE III

ACQUIRED RESISTANCE OF STAPH. AUREUS ON HABITUATION TO SPIRAMYCIN (15 TRANSFERS)

\begin{tabular}{c|c|c|c}
\hline $\begin{array}{c}\text { Strain of } \\
\text { Staph. aureus } \\
\text { Phage Type }\end{array}$ & \multicolumn{2}{|c}{ Increase* in Minimal Inhibitory Concentration of } \\
\cline { 2 - 4 } & Spiramycin & Erythromycin & Oleandomycin \\
\hline $42 \mathrm{D}$ & $>32$ & $>125$ & $>32$ \\
51 & 64 & 250 & $>64$ \\
80 & $>32$ & 250 & $>32$ \\
$42 \mathrm{E}$ & $>32$ & 4 & 16 \\
52 & 32 & 64 & 4 \\
47 & 4 & 8 & 2 \\
$47 \mathrm{~A}$ & 64 & 8 & 8 \\
\hline
\end{tabular}

* Expressed as multiples of the initial minimal inhibitory concentration.

staphylococci of different phage types through 15 subcultures in the presence of spiramycin; three showed a high degree of cross-resistance to oleandomycin, two showed little cross-resistance, and one acquired little resistance to spiramycin itself or to the other antibiotics of the group.

Cross-resistance with Other Antibiotics.-There was no consistent association in the resistance of staphylococci to erythromycin, penicillin, tetracycline, chloramphenicol, and novobiocin; the erythromycin-resistant staphylococci included a higher proportion of strains resistant to each of these antibiotics, presumably because they were all " hospital staphylococci" and reflected in their pattern of resistance the use of antibiotics in the ward.

\section{RESISTANCE OF OTHER BACTERIAL SPECIES}

\section{Streptococcus pyogenes}

During three years since we have used erythromycin, strains of Streptococcus pyogenes isolated from burns of four patients have been found resistant to erythromycin, in each case 
during or after a course of erythromycin therapy for a streptococcal infection. The resistant strains have been of two serological types ( 3 and 14). Each of these strains has shown cross-resistance to oleandomycin and to spiramycin by a ditch plate test. On re-testing two strains by the plate

TABLE IV

RELATIVE SENSITIVITY OF DIFFERENT WOUND ORGANISMS TO ANTIBIOTICS OF THE ERYTHROMYCIN GROUP

\begin{tabular}{ll|c|c|c}
\hline \multirow{2}{*}{ Antibiotic } & \multicolumn{2}{|c|}{ M.I.C. $(\mu \mathrm{g}$. per ml.) for 12 Sensitive Strains of } \\
\cline { 2 - 5 } & & Staph. aureus & Strep.pyogenes & Cl. welchii \\
\hline Erythromycin & $\ldots$ & 0.2 & $0.05-0.025$ & $0.2-0.1$ \\
Oleandomycin & $\ldots$ & $0.8-0.4$ & 0.4 & 3.2 \\
Spiramycin & $\ldots$ & $12 \cdot 5-6.25$ & $0.4-0.2$ & $0.4-0.2$ \\
\hline
\end{tabular}

dilution method, the M.I.C. of all three antibiotics was found to be $>100 \mu \mathrm{g}$. per ml. The M.I.C. of sensitive strains is shown in Table IV.

In the ditch plate test, resistant streptococci showed discrete colonies on the antibiotic ditch, although an undiluted broth culture was inoculated and gave confluent growth away from the ditch.

\section{Clostridium welchii}

One hundred strains of $\mathrm{Cl}$. welchii from air, dust, and burns were tested by the ditch plate method, with $10 \mu \mathrm{g}$. per $\mathrm{ml}$. of erythromycin and oleandomycin and $50 \mu \mathrm{g}$. per ml. of spiramycin in the ditch agar. All strains appeared sensitive to erythromycin and spiramycin and resistant to oleandomycin. All 24 strains of $\mathrm{Cl}$. tetani tested at the same time were sensitive to all three agents.

Plate dilution tests were then made on 12 of the strains of $\mathrm{Cl}$. welchii (see Table IV). These supported the findings of the ditch plate test, and showed $\mathrm{Cl}$. welchii to be consistently more sensitive to erythromycin and spiramycin than to oleandomycin. This was in contrast to the pattern shown by sensitive staphylococci, which were least sensitive to spiramycin, and Strep. pyogenes, which showed approximately the same sensitivity to oleandomycin and to spiramycin.

\section{PROPHYLAXIS AND THERAPY OF STAPHYLOCOCCAL INFECTION IN MICE}

From the anomalous results of sensitivity tests reported above, it is impossible to predict whether infection by a staphylococcus showing the sensitivity pattern $E R, O$ " $S$ " is likely to respond to therapy by oleandomycin. The question can only be answered satisfactorily by controlled therapeutic trials in man, but we have tried to throw some light on this problem by a series of mouse protection tests.

\section{Materials and Methods}

Strains of Staph. aureus. - The three strains selected were the same as those used for the growth curves shown in Fig. 2, representing three resistance patterns, viz., 57/7154 (ES, OS, SS), 57/7162 (ER, O "S," SS), and 57/8295 (ER, OR, SR); they were originally isolated from burns.

Overnight broth cultures of these organisms mixed with an equal volume of mucilage of tragacanth (B.P.C.) were injected in $0.1 \mathrm{ml}$. amounts intraperitoneally into albino mice. After several passages to increase virulence, undiluted inocula were found to kill from eight to 10 out of 10 mice within 24 hours; none was killed by the $10^{-1}$ inoculum.

Prophylactic and Therapeutic Tests.-Groups of 10 mice were used.

In the prophylactic tests, staphylococci were injected intraperitoneally as described above. One group was left untreated, and the others received intramuscular injections of erythromycin $(0.64 \mathrm{mg}$.), oleandomycin $(0.8 \mathrm{mg}$.), and spiramycin $(2.0 \mathrm{mg}$.) ; these weights of antibiotic were divided between four approximately four-hourly doses, the first being given at the time of the bacterial inoculation. The dosage was calculated to correspond, weight for weight, with the recommended human dosage. The number of animals surviving after 24 hours was recorded.

In the therapeutic tests the first dose of antibiotic was given two hours after the injection of staphylococci, and three further doses were given at four-hour intervals; the fully resistant strain was not included in the therapeutic experiment. Some of the tests were repeated with a higher dosage of oleandomycin $(1.6 \mathrm{mg}$.). The number of mice surviving after 10 hours and after 24 hours was recorded.

\section{Results}

Table $V$ summarizes the results of these experiments. In the prophylactic test, mice were fully protected by all three antibiotics against the sensitive staphylococcus (ES, OS, SS). Mice infected with the strain of pattern ER, $O$ " $S$," SS were apparently well protected by spiramycin (10 out of 10 survivors), less well protected by oleandomycin (seven out of 10 survivors), and least well protected by erythromycin (four out of 10 survivors). Against infection with the resistant strain (ER, OR, SR), however, oleandomycin and spiramycin were less active than erythromycin.

In the therapeutic tests, six out of 20 mice treated with erythromycin and 13 out of 30 mice treated with oleandomycin (at two dosages) were alive 24 hours after infection with strain ER, $O$ " S," SS compared with five out of 30 untreated controls which survived. The differences were not striking, but the result is consistent with findings in the prophylactic test, suggesting that oleandomycin has a small and erythromycin a 
TABLE V

PROPHYLAXIS AND THERAPY OF STAPHYLOCOCCAL INFECTION IN MICE

\begin{tabular}{|c|c|c|c|c|c|c|c|c|c|}
\hline \multirow{3}{*}{$\begin{array}{l}\text { Form of } \\
\text { Treatment }\end{array}$} & & \multirow{3}{*}{$\begin{array}{c}\text { Strain of } \\
\text { Staph. aureus }\end{array}$} & \multirow{3}{*}{$\begin{array}{c}\text { Sensitivity } \\
\text { Pattern }\end{array}$} & \multirow{3}{*}{$\begin{array}{c}\text { Hours After } \\
\text { Infection }\end{array}$} & \multicolumn{5}{|c|}{ Proportion of Mice (Groups of 10 ) Surviving under Treatment with } \\
\hline & & & & & \multirow{2}{*}{$\begin{array}{l}\text { Erythromycin } \\
\text { (0.8 mg.) }\end{array}$} & \multicolumn{2}{|c|}{ Oleandomycin } & \multirow{2}{*}{$\begin{array}{l}\text { Spiramycin } \\
\text { (2.0 mg.) }\end{array}$} & \multirow{2}{*}{$\underset{\text { Antibiotic }}{\text { No }}$} \\
\hline & & & & & & (0.64 mg.) & (1.6 mg.) & & \\
\hline Prophylactic & $\cdots$ & $\begin{array}{l}57 / 7154 \\
57 / 7162 \\
57 / 8295 \\
\end{array}$ & $\begin{array}{l}\text { ES, OS, SS } \\
\text { ER, O “S," SS } \\
\text { ER, OR, SR }\end{array}$ & $\begin{array}{l}24 \\
24 \\
24\end{array}$ & $\begin{array}{r}10 \\
4 \\
4\end{array}$ & $\begin{array}{r}10 \\
7 \\
1\end{array}$ & 二 & $\begin{array}{r}9 * \\
10 \\
2\end{array}$ & $\begin{array}{l}1 \\
2 \\
0\end{array}$ \\
\hline Therapeutic & $\cdots$ & $\begin{array}{r}57 / 7154 \text { (i) } \\
,, \quad \text { (ii) } \\
57 / 7162 \text { (i) } \\
,, \quad \text { (ii) } \\
, \quad \text { (iii) }\end{array}$ & $\begin{array}{c}\text { ES, OS, SS } \\
\text {," } \\
\text { ER, O “ S," SS } \\
\text {," } \\
\text {," }\end{array}$ & $\begin{array}{l}10 \\
24 \\
10 \\
24 \\
10 \\
24 \\
10 \\
24 \\
10 \\
24\end{array}$ & $\begin{array}{r}10 \\
8 \\
10 \\
10 \\
10 \\
4 \\
- \\
9 \\
2\end{array}$ & $\begin{array}{r}10 \\
1 \\
- \\
10 \\
2 \\
10 \\
4 \\
-\end{array}$ & $\begin{array}{l}\bar{z} \\
10 \\
10 \\
\bar{z} \\
\overline{10} \\
7\end{array}$ & $\begin{array}{l}10 \\
4 \\
- \\
10 \\
10 \\
= \\
=\end{array}$ & $\begin{array}{l}2 \\
0 \\
8 \\
2 \\
6 \\
0 \\
4 \\
1 \\
6 \\
4\end{array}$ \\
\hline
\end{tabular}

* Only nine mice were included in this group.

smaller therapeutic action against strains with the sensitivity pattern ER, $O$ " $S$ "; spiramycin appeared to have a greater therapeutic value for infection by these organisms. All three agents were more active in vivo against fully sensitive staphylococci.

\section{DISCUSSION}

The delayed growth of erythromycin-resistant Staph. aureus in the presence of oleandomycin sets a new problem in the interpretation of sensitivity tests not encountered with the other antibiotics. If the results after 18 hours' incubation are accepted, many strains would be described as sensitive which a reading at 42 hours would classify as resistant. It seems possible that a staphylococcal infection might be arrested by this retardation of growth in the presence of oleandomycin, especially as the organisms which do eventually break through the oleandomycin barrier (like those which at an earlier stage grew in the presence of erythromycin) appear to represent a minority of those present in the bacterial inoculum. Animal tests suggest that oleandomycin (and even erythromycin) may have some prophylactic and therapeutic action against such staphylococci, but the action is smaller than that exerted by either agent against genuinely sensitive strains.

It would seem from the incomplete nature of the cross resistance of staphylococci to erythromycin, spiramycin, and oleandomycin that each of these antibiotics has more than one mechanism of action against sensitive bacteria ; at least one mechanism is shared, but others are independent. The mechanism by which oleandomycin retards the growth of erythromycinresistant staphylococci from burns, for example, is not shared with erythromycin ; and spiramycin, which in these studies remained fully active against most of these erythromycin-resistant staphylococci, obviously has quite a different unshared mechanism of bacteriostasis. Spiramycin is the least active antibiotic of the group against sensitive Staph. aureus, and it seems also less closely related in this respect to the other two than they are to each other. Against $\mathrm{Cl}$. welchii, on the other hand, oleandomycin appears to be considerably less active than the other antibiotics of the group. Strep. pyogenes is most sensitive to erythromycin (cf. Garrod and Waterworth, 1956), and equally sensitive to oleandomycin and spiramycin. These differences in the relative sensitivity of different bacterial species to the three antibiotics are further evidence of the complexity of the bacteriostatic mechanisms involved.

\section{SUMMARY}

Sensitivity to erythromycin, oleandomycin, and spiramycin was tested by a ditch plate method on 620 strains of Staph. aureus isolated from burns during one month, and a selection of these and other staphylococci were tested also by tube and plate dilution methods. The tests were recorded after 18 hours' and again after 42 hours' incubation. Growth curves of staphylococci in the presence and in the absence of oleandomycin were plotted from viable counts.

Of the 267 strains $(43 \%)$ which were sensitive to erythromycin, all were sensitive to oleandomycin and 265 were sensitive to spiramycin in tests examined after 18 hours' incubation ; slightly reduced sensitivity was shown to oleandomycin in three of these strains when the tests were examined after 42 hours' incubation. Of the 353 strains $(57 \%)$ which were resistant or less sensitive to erythromycin, only 36 were fully sensitive to 
oleandomycin in tests examined after 18 hours, 211 strains showing intermediate sensitivity and 106 being fully resistant, i.e., showing growth across the ditch; when the tests were re-examined after 42 hours' incubation only five strains were fully sensitive to oleandomycin; 59 showed intermediate sensitivity and 289 were fully resistant. This altered pattern of resistance on continued incubation was not shown in tests with spiramycin, to which 259 of the erythromycin-resistant strains were sensitive after 18 hours and 258 after 42 hours' incubation.

Growth curves showed that erythromycinresistant oleandomycin-" sensitive" staphylococci began to multiply in the presence of oleandomycin after about 24 hours' lag, during which the number of viable organisms fell.

Mouse protection tests suggested that oleandomycin and even erythromycin might have some therapeutic action against staphylococci showing dissociated resistance to erythromycin, but the action was smaller than that of spiramycin against these strains or than any of the erythromycin group antibiotics against fully sensitive strains.
Spiramycin was the least active of these antibiotics against Staph. aureus, but oleandomycin was the least active against $\mathrm{Cl}$. welchii. Against Strep. pyogenes oleandomycin and spiramycin seemed to have about the same bacteriostatic activity. For these reasons and because of the incomplete pattern of cross resistance of Staph. aureus it seems that each of these antibiotics has more than one mechanism of action.

We wish to thank Mr. H. Lilly, F.I.M.L.T., and Mr. B. Collins for technical assistance, Mr. R. Gill for the photographs, and Mrs. M. Kilner for secretarial assistance.

\section{REFERENCES}

Garrod, L. P. (1957). Brit. med. J., 2, 57.

$\longrightarrow$ and Waterworth, P. M. (1956). Ibid., 2, 61

Hudson, D. G., Yoshihara, G. M., and Kirby, W. M. M. (1956). A.M.A. Arch. intern. Med., 97, 57.

Jones, W. F., Nichols, R. L., and Finland, M. (1956). Proc. Soc. exp. Biol. (N.Y.), 93, 388 .

Lowbury, E. J. L. (1957). Lancet, 2, 305.

Topley, E., and Hood, A. M. (1952). Ibid., 1, 1036.

Miles, A. A., Misra, S. S., and Irwin, J. O. (1938). J. Hyg. (Camb.), 38, 732 .

Needh im, G. M., and Geraci, J. E. (1956). Antibiot. Med., 3, 334.

Ross, S. (1956). Antibiot. Ann., 1955-56, p. 600.

Williams, R. E. O., and Rippon, J. E. (1952). J. Hyg. (Lond.), 50, 320. 